\title{
Interface Characterization of Ni/AI Bimetallic Explosively Welded Plate Manufactured with Application of Exceptionally High Detonation Speed
}

\author{
I. Kwiecien (ID, P. Bobrowski, M. Janusz-Skuza, A. Wierzbicka-Miernik, A. Tarasek, Z. Szulc, and J. Wojewoda-Budka
}

(Submitted May 7, 2020; in revised form August 18, 2020; published online September 23, 2020)

\begin{abstract}
The investigation is dedicated to the detailed microstructure characterization of explosively welded clads, in which, exceptionally and for cognitive purposes, a very high detonation speed of about $2800 \mathrm{~m} / \mathrm{s}$ was used to manufacture bimetallic aluminum-nickel plates. The study involves detailed microstructural characteristics of the bonded zone at micro and nano level, especially focused on the expanded melted regions consisted mostly of $\mathrm{Al}_{3} \mathrm{Ni}, \mathrm{Al}_{3} \mathrm{Ni}_{2}$ and $\mathrm{AINi}$ phases. In situ heating experiment in transmission electron microscope allowed observing microstructure transformation revealing that additionally present metastable $\mathrm{Al}_{9} \mathrm{Ni}_{2}$ phase was transformed to $\mathrm{Al}_{3} \mathrm{Ni}$ and $\mathrm{Al}_{3} \mathrm{Ni}_{2}$. Microhardness measurements across the welded zone showed the increase of the microhardness of nickel alloy plate from $153 \mathrm{up}$ to $170 \mathrm{HV}$ when approaching to the Ni201/A1050 interface, while the value for aluminum plate was of $45 \mathrm{HV}$. Within the melted zones the microhardness was found to be $135 \mathrm{HV}$ and it enormously increased to $850 \mathrm{HV}$ after annealing of the sample at $500{ }^{\circ} \mathrm{C}$. This change was due to the transformation of the interface region from the waves with the melted zones into the continuous layers of two intermetallic phases: $\mathrm{Al}_{3} \mathrm{Ni}$ and $\mathrm{Al}_{3} \mathrm{Ni}_{2}$. $\mathrm{The}$ second phase grew at the expense of the $\mathrm{Al}_{3} \mathrm{Ni}$.
\end{abstract}

Keywords aluminum alloys, explosive welding, interface, intermetallics, microstructure, nickel alloys

\section{Introduction}

Continuous technological development and search for engineering materials with unique properties for special applications comprises also advanced joining techniques. Thanks to the adjustment of technological parameters new simple (bimetallic tapes, plates) or complex (multilayered composites) materials are created. These materials are irreplaceable, wherever the external and internal working conditions are completely different or it is economically justified, e.g., cheap steel is covered by expensive alloy. The main areas for the use of this type of materials are the chemical, fuel and military industries. The coated materials can be produced by the chemical and electrochemical methods; however, on the large industrial scales, methods such as casting, cold rolling, or explosive welding (EXW) are successfully used (Ref 1-3). The EXW process, showed schematically in Fig. 1, is realized by acceleration of the flyer plate (fp) toward the base plate (bp) located underneath. The kinetic energy is released by the explosive materials located at the top of the flyer plate followed by the collision of both plates with very high speed. As a result,

I. Kwiecien, P. Bobrowski, M. Janusz-Skuza, A. WierzbickaMiernik, A. Tarasek, and J. Wojewoda-Budka, Institute of Metallurgy and Materials Science, Polish Academy of Sciences, 25 Reymonta St., 30-059 Cracow, Poland; and Z. Szulc, High Energy Technologies Works 'Explomet', 100H Oswiecimska St., 45-641 Opole, Poland. Contact e-mail: i.kwiecien@imim.pl. formation of the durable bond between them is obtained. Some parameters such as detonation velocity $\left(V_{\mathrm{d}}\right)$ or stand-off distance (SOD) between the colliding plates are the key factors influencing the morphology, microstructure and durability of the final interface. The boundary between the plates after EXW may possess one of three morphologies: flat, wavy, or wavy with continuous melted layer. Explosive welding of nickel and aluminum alloys is a promising joining technology for further application in multilayered materials production consisting from different metals and alloys, where the stable joint is produced between the materials characterized by completely different chemical and physical properties. There is, however, a gap among the literature reports regarding the Ni/Al welding. Only few publications are related to Ni/Al explosive weld (Ref 4-7), where either thin Ni coatings are welded with aluminum substrate (Ref 4 ) or multilayered Ni/Al composites are examined (Ref 5-7). Simple bimetallic weld-acting as a model set up to be investigated regarding the relation between the explosive welding process parameters and the bond microstructure/properties has not been studied, so far. In 2000 Garland et al. (Ref 4) studied explosively welded $\mathrm{Al} / \mathrm{Ni}$, where not the bulk plate but thin $\mathrm{Ni}$ foils were cladded on aluminum alloy substrates. This paper for the first time evidenced the possibility of joining aluminum and nickel by explosive welding method. Nevertheless, the characterization of the obtained connection was quite brief. More detailed description was given by Bataev et al. (Ref 6), who studied $\mathrm{Al} / \mathrm{Ni}$ multilayered composites. Authors focused on detailed microstructural characteristics at micro and nano scale, showing also microhardness profiles across the multilayers in the state directly after the welding and subjected to the further heat treatment at $620^{\circ} \mathrm{C}$. This challenging experiment revealed interesting dependency, unnoticed by the authors themselves at that time, but later in Ref 5 : the influence of the mutual localization of the colliding plates, which caused the formation of two types of interface. 


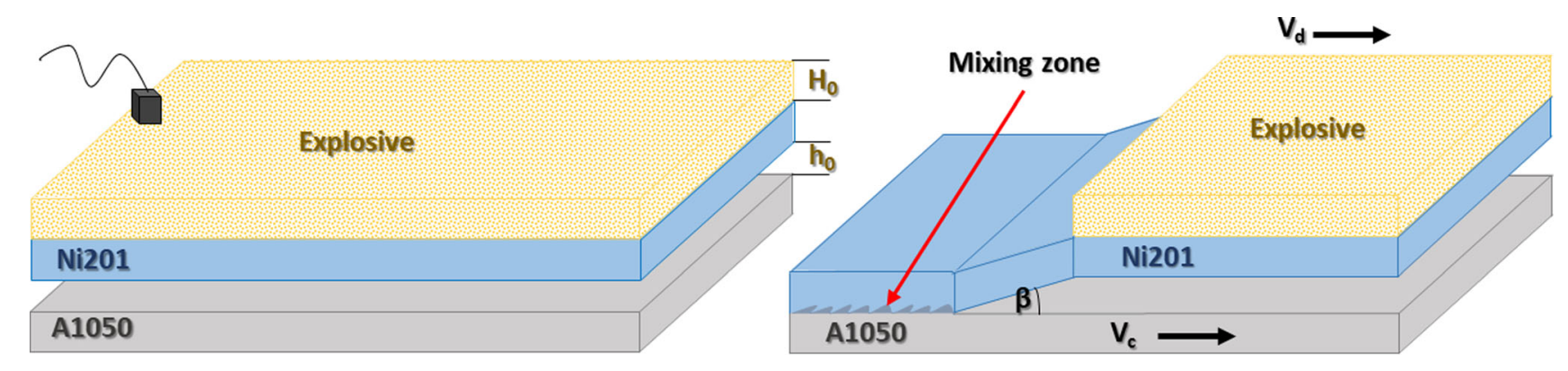

Fig. 1 Scheme of explosive welding process, where Ni201 is a flyer plate, A1050 is a base plate, $H_{0}$ - height of explosive mixture, $h_{0}$ - standoff distance, $\beta$-impact angle, $V_{\mathrm{d}}$-detonation velocity, $V_{\mathrm{c}}$-impact velocity (Ref 9)

First-nearly flat in the case, when $\mathrm{Ni}$ plate hits into the aluminum alloy and irregularly continuous melted area, when Al alloy acted as a flyer plate. On the other hand, Guo et al. (Ref 7) studied Ni/Al/Ni "sandwiches" manufactured by EXW technique, and observed that $\mathrm{Al} / \mathrm{Ni}$ interface was more wavy than its Ni/Al counterpart. Moreover, the observations using higher magnification revealed the influence of the applied stand-off distance between the colliding plates on the microstructure and mechanical properties of connections. Taking into account the important findings mentioned above, in this study the research program on the model bimetallic set up, consisting of two plates to be joined, has been undertaken, to extract the real influence of the welding parameters on the microstructure of the welds. Our first investigated and described type of weld (Ref 8), obtained using detonation velocity of $2400 \mathrm{~m} / \mathrm{s}$, indicated that the mutual location of the colliding plates was not significantly pronounced as it was in the case of very high detonation velocity applied to create the multilayered composites described in Ref 6. In Ref 8, bimetallic $\mathrm{Al} / \mathrm{Ni}$ and $\mathrm{Ni} / \mathrm{Al}$ clads evidenced only wavy morphology, and the difference was observed regarding the shape of the waves. Current work is a step further in accordance with our previous study described in Ref 8 and complementary to the cited above literature. As in the case of multilayered composites of promising applications, the detonation velocity has to be very high, our next questions arose-how the weld's morphology, microstructure and resulting properties will change if the detonation velocity will be raised. To answer these questions, it is necessary to perform the welding process with higher detonation velocity, while other experimental conditions are as close as possible to the previously applied ones and applied materials are the same. As the microstructure observations are one of the first and crucial steps, when designing the joining process parameters; therefore, this work is focused on the detailed microstructural characterization of $\mathrm{Ni} / \mathrm{Al}$ bimetallic clads manufactured with application of a very high detonation velocity compared to other works with respect to the amount of layers being joined, e.g., Ref 7. As the additional heat treatment is commonly applied in the industrial production as a stress relief annealing, the long-term heat treatment was additionally performed to follow the interface transformation and to compare how the microhardness across the weld changes directly after explosive welding and for the weld subjected to the additional heat treatment.

\section{Experimental}

Explosively welded bimetallic plate was produced with A1050 aluminum alloy as a base plate and Ni201 nickel alloy as a flyer plate. Detonation velocity was $2800 \mathrm{~m} / \mathrm{s}$. The cross sections of the samples in size of $15 \times 7 \times 2 \mathrm{~mm}$ were examined to reveal their microstructure. Scanning electron microscope (SEM) FEI Quanta 3D equipped with energy dispersive $\mathrm{X}$-ray spectrometer (EDS) and transmission electron microscope (TEM) Tecnai G2 F20 were used for microstructural observations and chemical composition determination. Additional in situ TEM observations were conducted using the heating holder in TEM with a heating rate of $10{ }^{\circ} \mathrm{C} / \mathrm{min}$. The thin foil was heated up to $450{ }^{\circ} \mathrm{C}$. Moreover, the interface region with melted areas was also examined using electron backscattered diffraction (EBSD) technique using EDAX Hikari device. Mechanical tests were conducted with microhardness tester CSM Instruments for samples in the state after explosive welding and additionally subjected to the annealing at $500{ }^{\circ} \mathrm{C}$ for $168 \mathrm{~h}$.

\section{Results and Discussion}

Continuous bond obtained with exceptionally high detonation velocity in explosive welding process consisted of many melted zones, indicating wavy character at the whole length of the connection, as it is shown in Fig. 2(a). The representative morphology, characteristic for most waves, is presented in Fig. 2(b). Massive melted regions, with many small particles dominated at the interface zone. Additionally, at the crest of waves, the swirled areas were noticed. These observations stay in good agreement with the literature data (Ref 4-7). Occasionally across the middle of the wave, the cracks were observed (Fig. 2b), which resulted most probably from very fast cooling of the melt. These cracks were observed only in the melted zones, and they did not propagate to the surrounding plates. Cracking is associated with the presence of the intermetallic phases formed in the melted regions, which in general weaken the connection zone due to their brittleness (Ref 10). Figure 3 shows other microstructural feature visible using higher magnifications. The melted region revealed the presence of the dendritic microstructure being typical for the fast cooling rates. Such dendrites were also observed in Ref 6, where Bataev et al. made a detailed description of the microstructure-equiaxed dendrites with micro size and smaller dendrites without branching. It was explained as a 
result of supercooling. Measurements of primary arms of the dendrites are presented in Fig. 3 allowed determine the average size to be close to $480 \mathrm{~nm}$ - it ranged from 250 to $670 \mathrm{~nm}$. On the other hand, secondary arms reached an average size of $240 \mathrm{~nm}$ (they varied between 150 and $350 \mathrm{~nm}$ ). These dimensions are greater than measured by Bataev et al. who determined $300 \mathrm{~nm}$ as a size of primary arms and $79 \mathrm{~nm}$ - for secondary arms (Ref 6). Such discrepancy arose most probably from lower detonation velocity applied in current study thus lower critical cooling rates during explosive welding.

Typical melted region shown in Fig. 2(b) was also verified in terms of its chemical composition, grain size and their crystallographic orientation. EDS measurements presented in the form of elements distribution maps (Fig. 2c, d) revealed that the melted area was mostly enriched in aluminum; however, small particles visible inside the melted zone were mainly rich

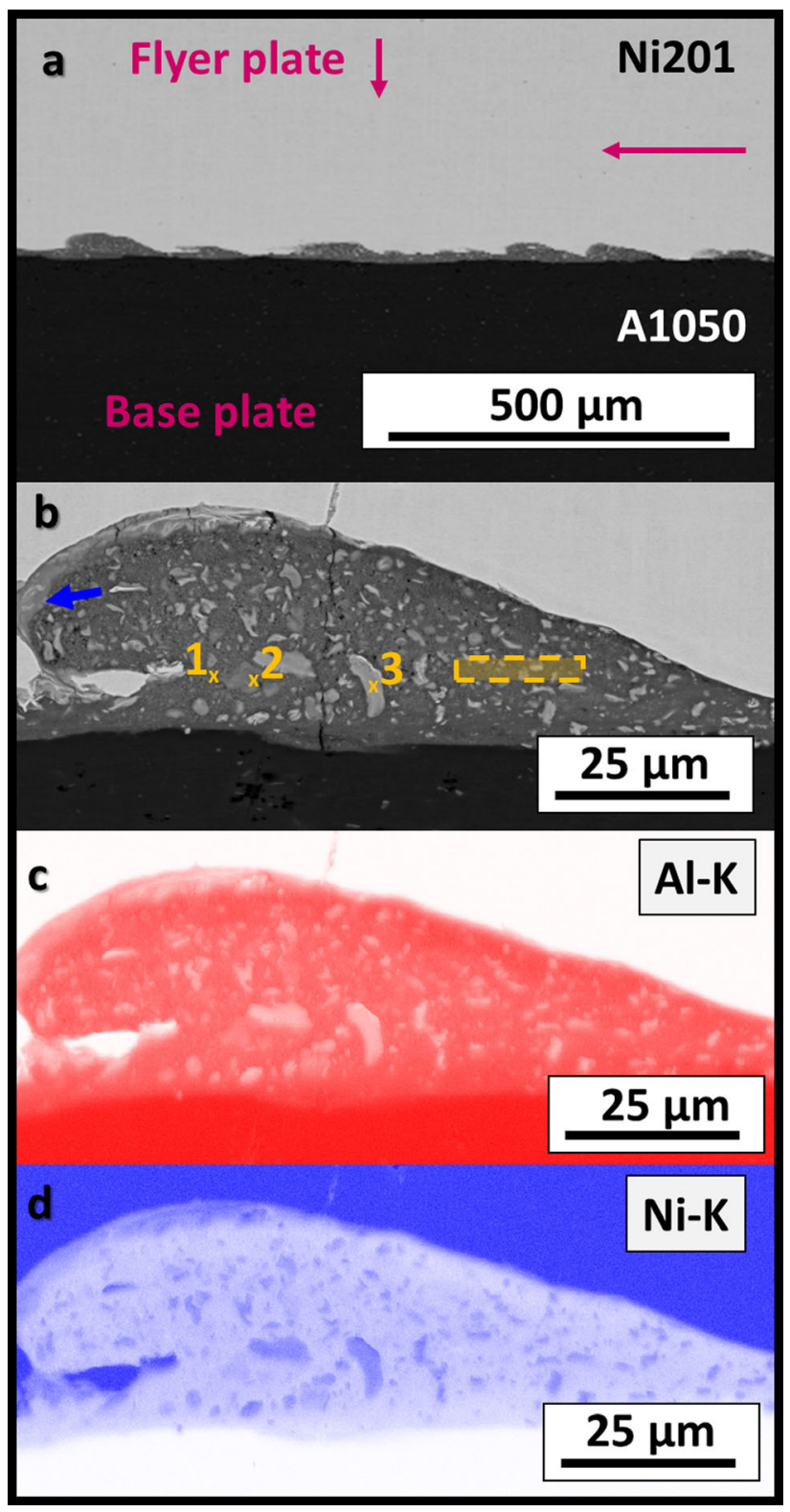

Fig. 2 Ni201/A1050 after EXW: overall view of wavy interface (a), microstructure of individual and typical wave in BSE contrast (b), SEM-EDS maps of Al-K $\alpha$ (c) and $\mathrm{Ni}-\mathrm{K} \alpha$ (d) distribution in nickel. It was also confirmed by the chemical composition point analysis with the EDS method (Fig. 2b). Measurements were performed in many places, the most representative examples of which are marked in Fig. $2 b$ with numbers of 13. Collected data allowed to determine phases such as: 1) $\mathrm{Al}_{3} \mathrm{Ni}$ (73.5 at.\% of $\mathrm{Al}$ and 26.5 at. $\%$ of $\mathrm{Ni}$ ), 2) $\mathrm{Al}_{3} \mathrm{Ni}_{2}$ (61.2 at.\% of $\mathrm{Al}$ and 38.8 at.\% of $\mathrm{Ni}$ ) and 3) $\mathrm{AlNi}$ (54.5 at.\% of $\mathrm{Al}$ and 45.5 at.\% of $\mathrm{Ni}$ ). Presented results are consistent with the literature data in terms of chemical composition (Ref 5-7) and character of microstructure features (Ref 4-7); however, overall appearance of the interface is unlike. Similar SEM microstructures were reported by Gerland et al. (Ref 4), who manufactured the bilayer plates as in the current work. They applied high detonation velocity (in the range of 2400 to $3900 \mathrm{~m} / \mathrm{s}$ ) to join the $\mathrm{Al}$ alloy base plate with $\mathrm{Ni}$ in the form of foil of 50 and $100 \mu \mathrm{m}$ in thickness. Bataev et al. (Ref 6) applied even higher $(4200 \mathrm{~m} / \mathrm{s})$ detonation velocity to weld many multiple alternating nickel and aluminum layers. In both these cases and in here described experiment, the application of the high detonation velocity resulted in the large amount of the melted regions and intermetallic phases at the interface, as well as significant amplitude and wave length increase. Moreover, this followed intensification of the tendency to microcracks formation, which not propagated farther to substrates. Referring also to our previous study (Ref 8) the above tendency is preserved. Reduction of the detonation velocity to $2400 \mathrm{~m} / \mathrm{s}$ irrespectively of plates' mutual localization (Ref 8) resulted in change of the waves shape to more slender and less massive. Dendritic microstructure was also observed.

As it was mentioned above, in explosively welded Ni/Al multilayered composites the interface microstructure varied depending on the mutual localization of the colliding plates. Ogneva et al. (Ref 5) indicated that if the top colliding plate is $\mathrm{Ni}$, the flat interface is formed, but if $\mathrm{Al}$ is on the top, the interface is broader and of irregular shape. Guo et al. (Ref 7) showed three types of explosive "sandwiches" Ni/Al/Ni, which were formed by changing some welding parameters. With increasing stand-off distance $\mathrm{Ni} / \mathrm{Al}$ (Ni plate located on the top) the interface changed from the flat one by the wavy to continuous melted layer. For the lowest stand-off distance, both $\mathrm{Ni} / \mathrm{Al}$ and $\mathrm{Al} / \mathrm{Ni}$ interfaces are flat, in two other cases $\mathrm{Al} / \mathrm{Ni}$ interfaces have more pronounced wavy character. Nevertheless, it should be always kept in mind that the analytical resolution limit of SEM-EDS method is usually insufficient when collecting the $\mathrm{x}$-ray signal coming from the closely neighboring small areas.

Additionally, the SEM-EBSD color code map of phases has been collected (Fig. 4b), which evidenced that inside of the melted area, the $\mathrm{Al}_{3} \mathrm{Ni}$ (yellow region) constitutes the matrix with blue areas of AlNi randomly distributed. Other colors represent as follows: red for aluminum and green for nickel. These observations are compatible with SEM-BSE image and the EDS maps. Additionally, in Fig. 4(a), the EBSD map of melted area and its nearest surrounding is presented. The region, which was melted is impossible to be properly indexed, and it is associated with the strong plastic deformation of this region, its refinement and inhomogeneity of the chemical composition mentioned above. Refinement of the microstructure in the close neighborhood and within the mixing zone is typical for explosive welding process. Among others, Fronczek et al. (Ref 11) indicated that the visible grain refinement in Al/ Ti/Al EXW "sandwich" involved areas directly close to the 


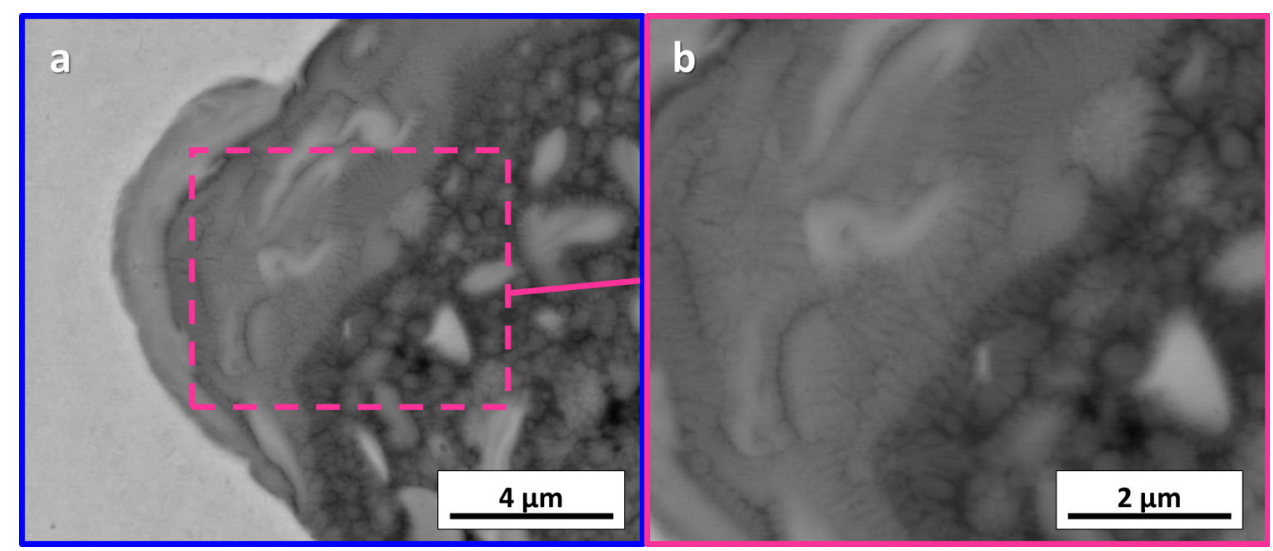

Fig. 3 SEM-BSE image of dendritic microstructure of the melted region, indicted by blue arrow in Fig. 2b (a) and higher magnification of this area (b)

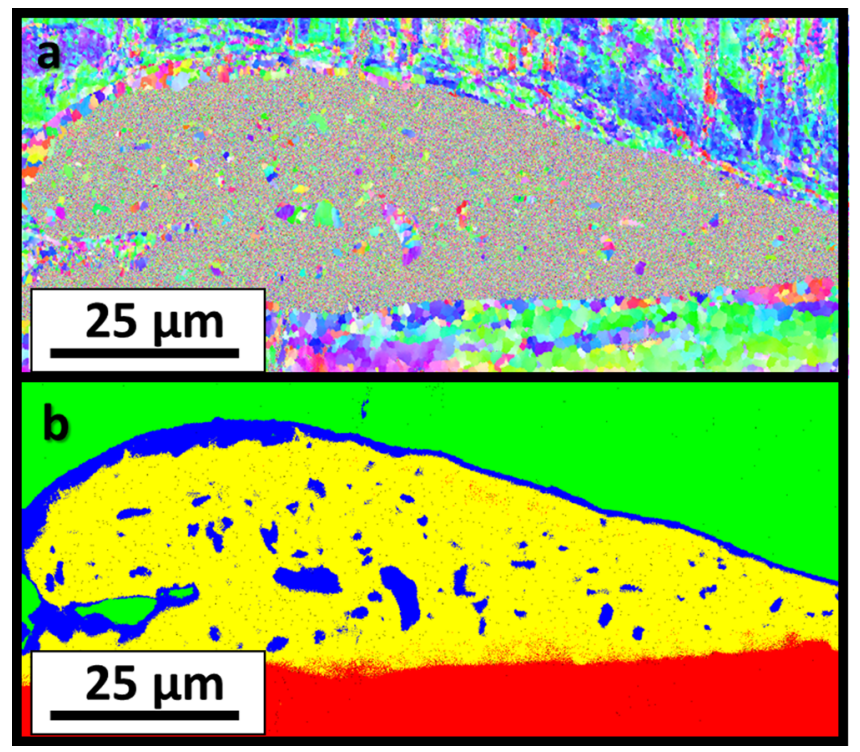

Color Coded Map Type: Inverse Pole Figure [001]

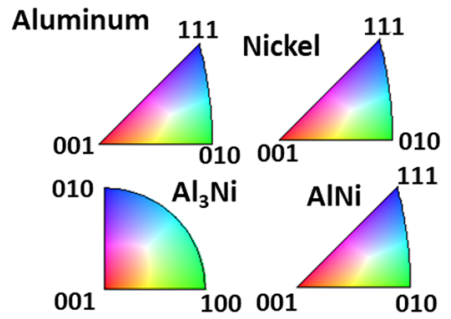

Color Coded Map Type: Phase

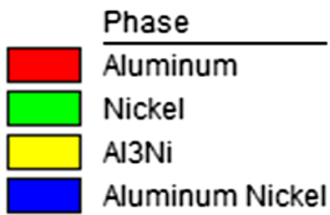

Fig. 4 Ni201/A1050 after EXW: SEM-EBSD map showing strong grain refinement inside of the wave (a) as well as the distribution of the phases in this particular region of interest (b)

joint, with more pronounced effect for the interface localized nearer to the explosive mixture.

In order to verify the results obtained by SEM technique, a thin foil for TEM observations was cut using focused ion beam (FIB) technique from the middle part of the melted area presented in Fig. 2(b) and marked with yellow frame. This region is the representative one regarding all the melted zones observed across the weld. Its microstructure was composed of many fine equiaxed grains with size between 200 and $500 \mathrm{~nm}$ embedded in the matrix, as it is shown in TEM bright-field images in Fig. 5. Selected area diffraction patterns revealed the presence of two rich in aluminum intermetallic phases present in the equilibrium phase diagram: $\mathrm{Al}_{3} \mathrm{Ni}_{2}$ (Fig. 5a) and $\mathrm{Al}_{3} \mathrm{Ni}$ (Fig. 5b). However, also creation of $\mathrm{Al}_{9} \mathrm{Ni}_{2}$ took place (Fig. 5c), which can be formed only under strongly nonequilibrium conditions, e.g., rapid solidification. This metastable phase was previously observed by Bataev et al. (Ref 6) within the melted region localized at fourth interface of $\mathrm{Ni} / \mathrm{Al}$ multilayered composites, although in the described here experiment the detonation velocity was significantly lower ( 2800 versus $4200 \mathrm{~m} / \mathrm{s}$ ). In Ref 6, however, the size of the rounded as in here precipitates was twice smaller (below $100 \mathrm{~nm}$ ). In both works this phase was distributed irregularly. During the joining process, welded materials are turbulently mixing with each other under extremely high pressure, while cooling is very fast (microseconds). Such conditions of the process of joining eliminate possibility of homogenization of the melted region (Ref 6). However, further decreasing of the detonation velocity value to $2400 \mathrm{~m} / \mathrm{s}$ described in Ref 8 , results in lack of the metastable phase. Taking into account that metastable phases present at the interface will contribute to the formation of the stable intermetallics due to the post-heat treatment it is important regarding the goal application, which value of the detonation velocity should be applied. It should be also reminded that $\mathrm{Al}_{9} \mathrm{Ni}_{2}$ metastable phase has been shown for the first time by $\mathrm{Li}$ and Kuo (Ref 12), who considered it as isostructural with $\mathrm{Al}_{9} \mathrm{Co}_{2}$ phase, and it was later confirmed by Pohla and Ryder (Ref 13). More precise information on $\mathrm{Al}_{9} \mathrm{Ni}_{2}$ 


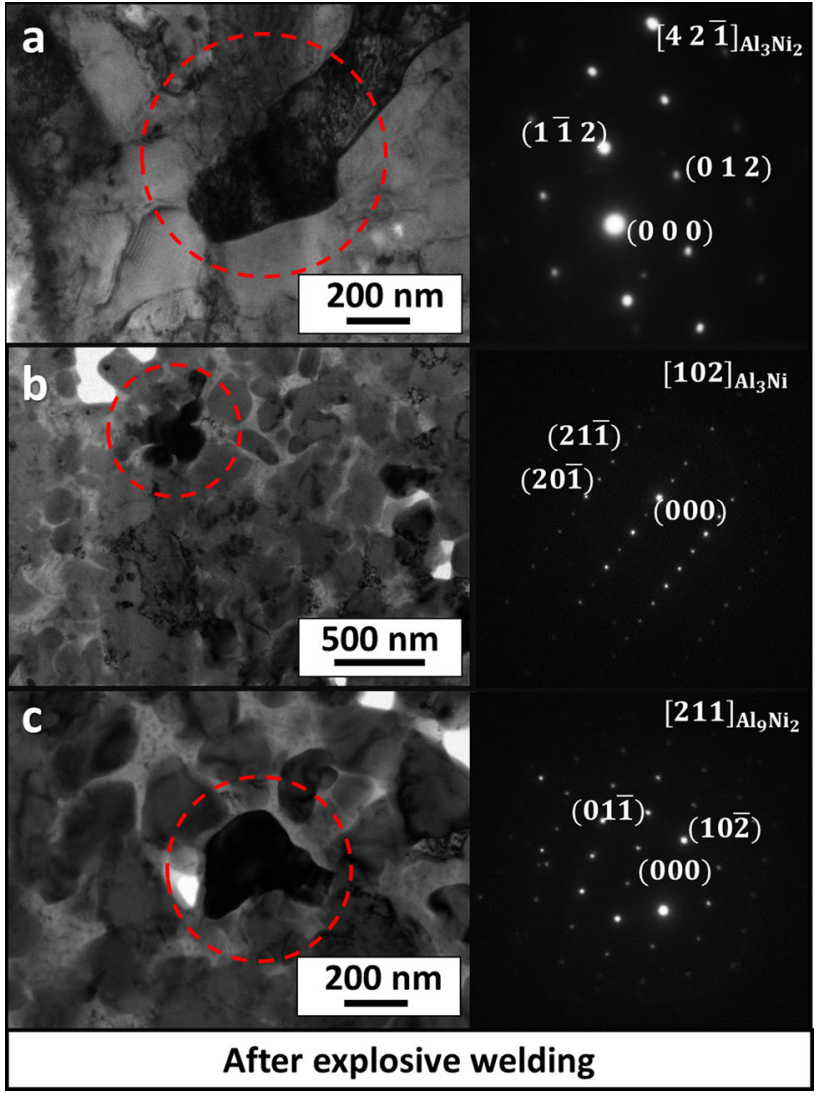

Fig. 5 TEM bright field images showing the microstructure of the melted zone formed due to the explosive welding of A1050 with Ni201 together with the corresponding SAED patterns taken from the grains marked with circles: $\mathrm{Al}_{3} \mathrm{Ni}_{2}$ (a), $\mathrm{Al}_{3} \mathrm{Ni}$ (b), $\mathrm{Al}_{9} \mathrm{Ni}_{2}$ (c)

phase such as lattice parameters and atoms positions can be found in work of Yücelen (Ref 14), where various lowdimensional structures were examined with the aim of transmission electron microscopy. Detailed data concerning the lattice parameters and atomic positions of $\mathrm{Al}_{9} \mathrm{Ni}_{2}$, used to solve the diffraction patterns are collected in Table 1. Presence of $\mathrm{Al}_{9} \mathrm{Ni}_{2}$ phase was also confirmed in studies on $\mathrm{Al} / \mathrm{Ni}$ multilayered films in first stages of their annealing (Ref 15, 16). Its occurrence was explained by existence of supersaturated solid solution of $\mathrm{Ni}$ in $\mathrm{Al}$ at $\mathrm{Al} / \mathrm{Ni}$ interfaces and excess of vacancies in multilayers films, which caused the diffusion and then formation of metastable $\mathrm{Al}_{9} \mathrm{Ni}_{2}$ phase due to atomic displacement (Ref 15). It is possible that in the case of high detonation velocity as a result of fast cooling rate supersaturated solid solution (Al) transferred to metastable $\mathrm{Al}_{9} \mathrm{Ni}_{2}$. In Ref 15 , due to subsequent heating, $\mathrm{Al}_{9} \mathrm{Ni}_{2}$ phase transformed to equilibrium forms such as $\mathrm{Al}_{3} \mathrm{Ni}$ or $\mathrm{Al}_{3} \mathrm{Ni}_{2}$. However, in our case-after EXW, the coexistence of equilibrium and metastable phases were observed, which means that probably simultaneously more mechanisms may be responsible for the interface's microstructure formation. Studies concerning Al/Ni multilayer foils with different thickness prepared by magnetron sputtering (Ref 16) indicated that the formation of the $\mathrm{Al}_{9} \mathrm{Ni}_{2}$ during annealing is related to the thickness of the foil and in the case of bilayer foils with the smallest thickness instead of metastable $\mathrm{Al}_{9} \mathrm{Ni}_{2}$ the equilibrium $\mathrm{Al}_{3} \mathrm{Ni}$ was found. The morphology of $\mathrm{Al}_{9} \mathrm{Ni}_{2}$ after explosive welding was of globular grains unevenly distributed in the mixing zone-Fig. 5(c) and
Ref 6 . In contrary to this, in the multilayered foils $\mathrm{Al}_{9} \mathrm{Ni}_{2}$ phase was growing along $\mathrm{Al} / \mathrm{Ni}$ interface and $\mathrm{Al}$ grain boundaries (Ref 16).

Elemental mapping shown in Fig. 6(b), (c) and (d) indicates differences in distribution of $\mathrm{Al}, \mathrm{Ni}$ and $\mathrm{Fe}$. The last element is the additive of both initial alloys being explosively welded. The chemical composition analysis using EDS confirmed the phases identified by electron diffraction, where the average atomic percentage of each phase is given as follows: $\mathrm{Al}_{3} \mathrm{Ni}$ : 73.4 at. $\%$ of $\mathrm{Al}$ and 26.6 at. $\%$ of $\mathrm{Ni}, \mathrm{Al}_{3} \mathrm{Ni}_{2}: 65.4$ at.\% of $\mathrm{Al}$ and 34.6 at. $\%$ of $\mathrm{Ni}$ and $\mathrm{Al}_{9} \mathrm{Ni}_{2}: 85.2$ at.\% of $\mathrm{Al}$ and 14.8 at.\% of Ni.

Equilibrium phase diagram indicates the possibility of formation from the liquid state the eutectic mixture, which consists of 97.3 at.\% of $\mathrm{Al}$ and 2.7 at.\% of Ni (Ref 17). EDS chemical composition analyses from the areas between the fine grains of the intermetallic phases defined as a matrix (Fig. 6a) indicated that this zone consisted of the eutectic mixture of $\mathrm{Al}$ solid solution and $\mathrm{Al}_{3} \mathrm{Ni}$ phase. In such areas, the average atomic percentage of aluminum was equal 97.7 at.\% and 2.3 at. $\%$ of $\mathrm{Ni}$.

The formation of eutectic mixture is associated with solidification of these regions from the liquid phase. From a thermodynamic point of view, solidification cannot take place exactly at the eutectic temperature as this would entail the formation of an eutectics with infinitely large inter-plate distances. High cooling rates are used to obtain the eutectics and this means that the growth of eutectics takes place in conditions that deviate from equilibrium, which is a case in here. Obtained very fine eutectics presented in Fig. 6 with the distances between the plates in the range of nanometers is one more indication of an extremely fast cooling.

Heating with the aim of TEM equipped with the heating holder was applied to observe in situ the changes occurring within the melted zone, thanks to which the transformation of $\mathrm{Al}_{9} \mathrm{Ni}_{2}$ phase was recorded. There are two reasons for which the microstructure and intermetallic phase transformations are important to be studied: (1) the post-heat treatment is an industrial step applied usually for the explosively welded clads as the stress relief annealing; (2) promising application of multilayered $\mathrm{Al} / \mathrm{Ni}$ welds as a metallic-intermetallic laminates presented in Ref 6 force the exact control of the intermetallics growth. After post-processing heating of the thin foil in vacuum up to $450{ }^{\circ} \mathrm{C}$, the microstructure changes were recorded (Fig. 7). It was important to perform the observation of the metastable phase transformation, which significantly influence the mechanical properties of the weld as it will be presented further. An uncontrolled transformation of metastable phases to equilibrium forms due to the annealing, thus rapid changes of their properties, has to be taken into account. In situ heating in TEM revealed the growth of the smaller grains to about $500 \mathrm{~nm}$, while the selected area electron diffraction (SAED) patterns confirmed the existence of only stable intermetallic phases: $\mathrm{Al}_{3} \mathrm{Ni}$ and $\mathrm{Al}_{3} \mathrm{Ni}_{2}$. According to Pohla et al. (Ref 13), under conditions of post-processing heating the metastable $\mathrm{Al}_{9} \mathrm{Ni}_{2}$ phase should transform to $\mathrm{Al}_{3} \mathrm{Ni}$ and $\mathrm{Al}$, while in Ustinov et al. work (Ref 15) it transformed to both $\mathrm{Al}_{3} \mathrm{Ni}$ and $\mathrm{Al}_{3} \mathrm{Ni}_{2}$ phases.

Bulk samples were also subjected to annealing at $500{ }^{\circ} \mathrm{C}$ for $168 \mathrm{~h}$ in laboratory furnace to observe the transformation of the interface after prolonged heat treatment. Experiment confirmed that after heat treatment the mixing zone transformed to $\mathrm{Al}_{3} \mathrm{Ni}$ and $\mathrm{Al}_{3} \mathrm{Ni}_{2}$ phases growing in the form of continuous layers 
Table 1 Lattice parameters and atom positions of metastable $\mathrm{Al}_{9} \mathrm{Ni}_{2}$ phase based on data published in $\mathrm{Ref} 14$

\begin{tabular}{|c|c|c|c|c|c|c|}
\hline \multicolumn{3}{|c|}{ Lattice parameters } & \multicolumn{4}{|c|}{ Atom position } \\
\hline & $(\AA)$ & Space group & Non-equivalent position & $x$ & $y$ & $z$ \\
\hline \multirow[t]{2}{*}{$a$} & $8.683(1)$ & $\mathrm{P} 2{ }_{1} / \mathrm{a}$ & Al1 & 0 & 0 & 0 \\
\hline & & & $\mathrm{A} 12$ & $0.2524(4)$ & $0.0024(13)$ & $0.4083(4)$ \\
\hline \multirow[t]{2}{*}{$b$} & $6.261(2)$ & & $\mathrm{A} 13$ & $0.5468(4)$ & $0.120(11)$ & $0.2157(5)$ \\
\hline & & & $\mathrm{A} 14$ & $0.0023(4)$ & $0.1742(12)$ & $0.3585(6)$ \\
\hline$c$ & $6.192(2)$ & & $\mathrm{A} 15$ & $0.2373(4)$ & $0.3016(12)$ & $0.0825(6)$ \\
\hline$\beta$ & $96.5^{\circ}$ & & $\mathrm{Ni}$ & $0.8418(17)$ & $0.139(6)$ & $0.2789(3)$ \\
\hline
\end{tabular}

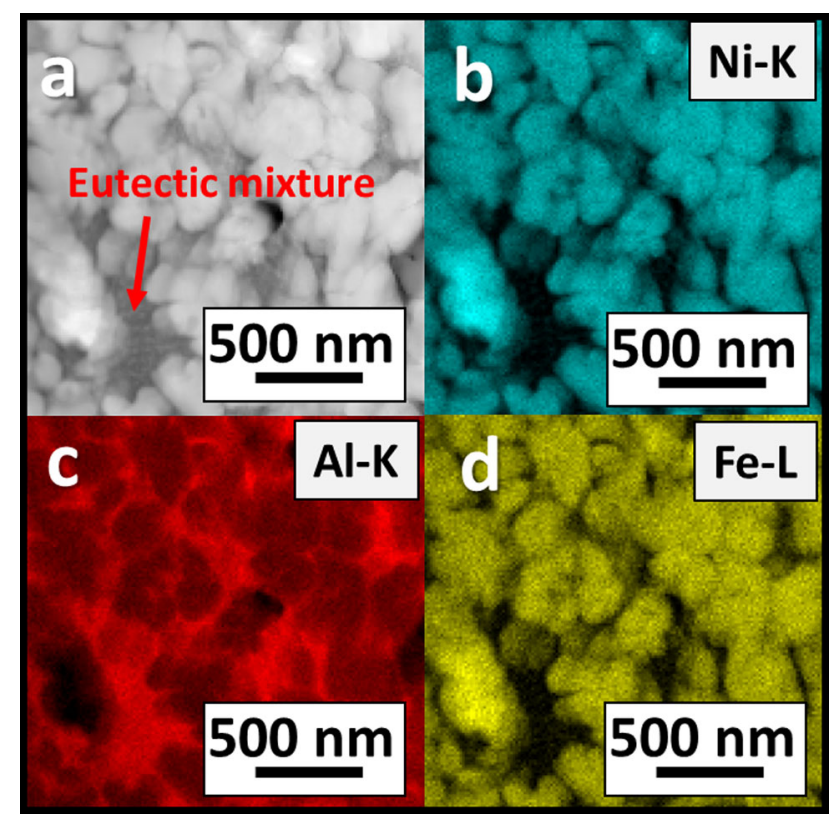

Fig. 6 STEM image indicating the area identified as eutectic mixture of $\mathrm{Al}$ and $\mathrm{Al}_{3} \mathrm{Ni}$ phase 97.7 at.\% $\mathrm{Al}$ and 2.3 at.\% of $\mathrm{Ni}$ (a) and TEM-EDS maps of $\mathrm{Ni}$ (b), $\mathrm{Al}$ (c) and $\mathrm{Fe}$ (d) distribution within the investigated region of interest

and located in the following order: $\mathrm{A} 1050 / \mathrm{Al}_{3} \mathrm{Ni} / \mathrm{Al}_{3} \mathrm{Ni}_{2} / \mathrm{Ni} 201$. Figure 8 presents the microstructure after annealing with indication of the average thickness of overall bonding zone, $\mathrm{Al}_{3} \mathrm{Ni}_{2}$ and $\mathrm{Al}_{3} \mathrm{Ni}$, reaching the values: 130, 110 and $20 \mu \mathrm{m}$, respectively. At the $\mathrm{Al}_{3} \mathrm{Ni}_{2} / \mathrm{Al}_{3} \mathrm{Ni}$ interface the porosity was observed, occurring locally in form of clusters or distributed along the line perpendicular to the phases' boundary and within both intermetallic layers. Presence of the porosity may be a result of fast growth of the intermetallic phases. Ogneva et al. (Ref 5) also evidenced porosity along $\mathrm{Al}_{3} \mathrm{Ni}_{2} / \mathrm{Al}_{3} \mathrm{Ni}$ interface after annealing at $620{ }^{\circ} \mathrm{C}$ for $5 \mathrm{~h}$; however, it was localized mainly within $\mathrm{Al}_{3} \mathrm{Ni}_{2}$ phase. Authors did not comment on it. In case of current investigation growth rate of intermetallic phases was slower than reported in Ref 5 due to lower annealing temperature. After $168 \mathrm{~h}$ thickness of overall interface reached $130 \mu \mathrm{m}$, where $110 \mu \mathrm{m}$ constituted the thickness of $\mathrm{Al}_{3} \mathrm{Ni}_{2}$ and $20 \mu \mathrm{m}$ thickness of $\mathrm{Al}_{3} \mathrm{Ni}$. In Ref 5, as two types of interfaces $\mathrm{Al} / \mathrm{Ni}$ and $\mathrm{Ni} / \mathrm{Al}$ were distinguished the thickness of the intermetallics' layers was measured to be near $100 \mu \mathrm{m}$ and $50 \mu \mathrm{m}$, respectively. Additionally, in agreement with our

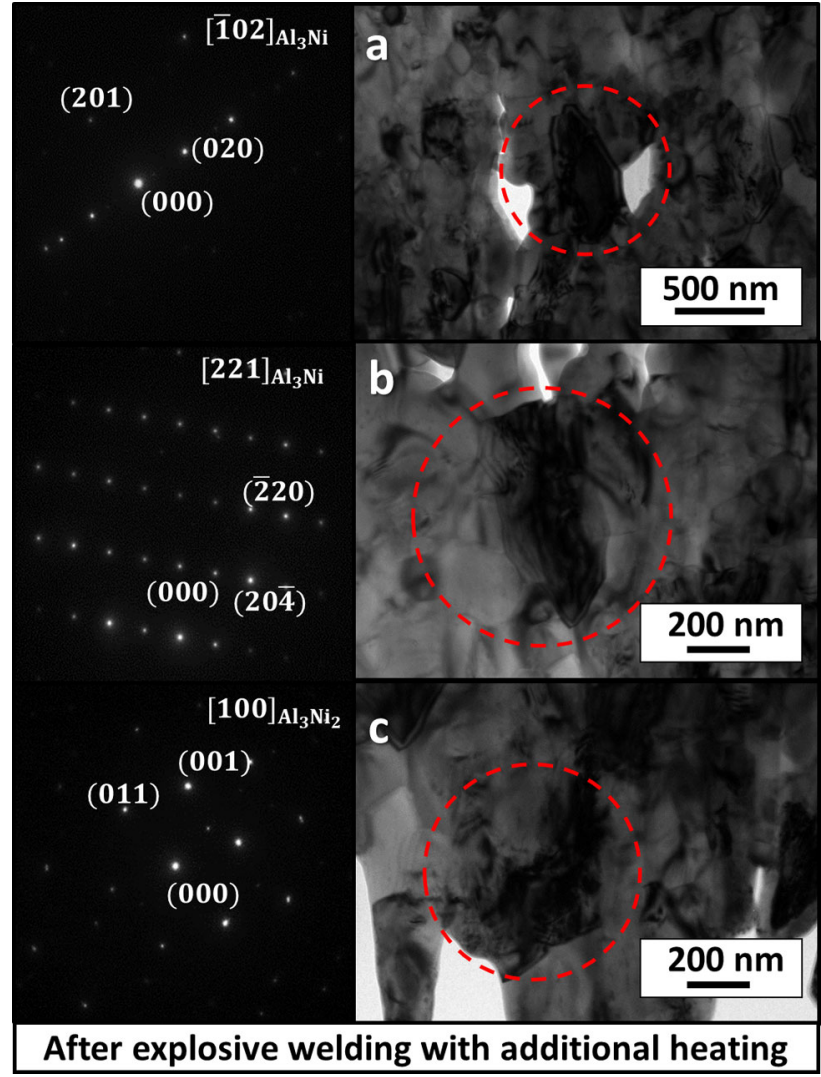

Fig. 7 TEM bright field images showing the changes of microstructure of the melted zone after the additional heating together with the corresponding SAED patterns taken from the grains marked with circles: $\mathrm{Al}_{3} \mathrm{Ni}(\mathrm{a}, \mathrm{b})$ and $\mathrm{Al}_{3} \mathrm{Ni}_{2}$ (c)

previous results (Ref 8) also in this study after long-term annealing phase enriched in 4 at. $\%$ of Fe occurred at $\mathrm{Al} / \mathrm{Al}_{3} \mathrm{Ni}$ interface. The Al-Ni-Fe phase (consisting of 4.0 at.\% of $\mathrm{Fe}$, 13.0 at.\% of $\mathrm{Ni}, 83.0$ at.\% of $\mathrm{Al}$ ) was distributed both along the interface and in the form of islands within the A1050 alloy nearby. This phase was not observed by other authors, who studied annealed Al/Ni explosively welded clads (Ref 5, 6). More detailed study of phase enriched in iron is essential to be performed in the future.

Microhardness tests were conducted on samples in the state after EXW (Fig. 9a) and after annealing (Fig. 9b) without protecting atmosphere at $500{ }^{\circ} \mathrm{C}$ for $168 \mathrm{~h}$. These microhardness measurements were performed within the areas without 


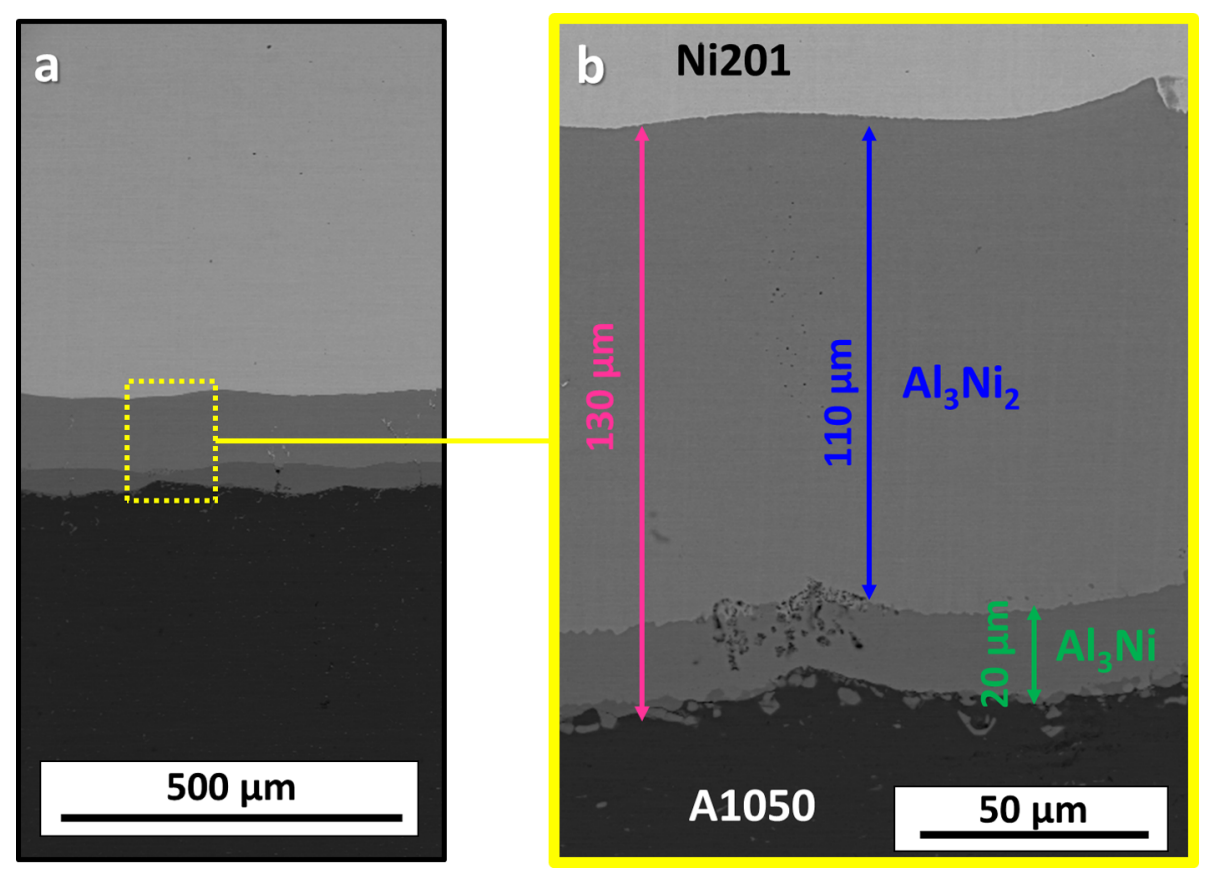

Fig. 8 SEM-BSE images presenting overall view of the interface's microstructure after annealing at $500{ }^{\circ} \mathrm{C}$ for $168 \mathrm{~h}$ in laboratory furnace: general view (a) and magnified image with indicated average thickness of particular zones (b)

defects such as cracks. The initial average microhardness of the flayer (Ni201) and base plate (A1050) was 104 and $35 \mathrm{HV}$, respectively. Figure 9 a shows changes measured across of Ni210/A1050 clads directly after explosive welding. The average microhardness for nickel alloy plate was of $160 \mathrm{HV}$; however, slight increase of microhardness with the decrease of the distance to the bond area was observed. Measurement located at the farthest distance from the melted area was of $153 \mathrm{HV}$, while the value of $170 \mathrm{HV}$ was reached very close to the interface. In the case of $\mathrm{Al}$ alloy, the growth of microhardness near the bonding area was also observed; however, the highest value of $45 \mathrm{HV}$ was achieved for the indentation point localized at the nearest area to the contact base plate with the groundwork, while the average microhardness of A1050 was significantly lower in comparison to nickel alloy reaching only $40 \mathrm{HV}$, nevertheless, the tendency of increasing microhardness, when approaching to the interface, was not observed in this case. Relation of increasing microhardness value in the neighborhood of mixing zone is related to the strengthening and grain refinement due to collision of plates with high velocity and it was previously also observed in other works (Ref 11, 18-20). Microhardness of initial materials reported in Ref 6 were similar to ours-100 HV (Ni plate) and $30 \mathrm{HV}$ (Al plate) and increased after EXW to 190 and $50 \mathrm{HV}$ - slightly more than in here examined welds, which can be the result of higher strengthening of the material due to stronger impact. The areas of the melted regions allowed make the measurement only at one place in the middle of the wave. The average microhardness taken at these regions was of $315 \mathrm{HV}$. In Ref 6 , the microhardness measurements in the melted regions varied between 450 and $700 \mathrm{HV}$; however, the error bars were also significantly high and our microhardness values are falling within the lower part of measurements' standard deviations as shown in Fig. 6 in Ref 6. After annealing of the weld at $500{ }^{\circ} \mathrm{C}$ (Fig. 9b), the microhardness of $\mathrm{Ni}$ and $\mathrm{Al}$ alloy plates were lower in comparison to the state directly after EXW reaching
140 and $22 \mathrm{HV}$, respectively. For Ni201 plate the highest hardness was measured at the place located in the neighborhood of the reaction zone. Bataev et al. (Ref 6) reported also decrease of microhardness of the aluminum and nickel after annealing explaining this by the rearrangement of the dislocation structure observed with TEM. Despite the fact that the reaction zone after annealing was composed of two continuously growing layered phases $\mathrm{Al}_{3} \mathrm{Ni}$ and $\mathrm{Al}_{3} \mathrm{Ni}_{2}$, due to the limited thickness of $\mathrm{Al}_{3} \mathrm{Ni}$, it was possible to determine only the microhardness for $\mathrm{Al}_{3} \mathrm{Ni}_{2}$ to be $830 \mathrm{HV}$. The shapes of all Vickers indentations were more or less regular squared with visible diagonals. Bataev et al. annealed the EXW multilayered composite at $620{ }^{\circ} \mathrm{C}$ for $3 \mathrm{~h}$, which resulted in formation of $\mathrm{Al}_{3} \mathrm{Ni}$ and $\mathrm{Al}_{3} \mathrm{Ni}_{2}$ phases at the interface between the joined plates. It was observed that hardness of $\mathrm{Al}_{3} \mathrm{Ni}_{2}$ was much harder than the melted area after EXW and was in the range of 700-1100 HV. This variation can be associated with the measurements performed either within $\mathrm{Al}_{3} \mathrm{Ni}$ or $\mathrm{Al}_{3} \mathrm{Ni}_{2}$ phase.

\section{Conclusion}

The literature regarding explosive welding of $\mathrm{Al}$ with $\mathrm{Ni}$ alloys comes down basically to a few papers, where rather complicated set up was a subject of study - either a thin foil of nickel joined with the aluminum substrate or a multilayered composite. Used in this study simple bimetallic set up acts as a starting point to reveal and understand the phenomena occurring due to extreme conditions of explosive welding. This paper and the previous one described in Ref 8 bring information that will improve the designing process of aluminum-nickel explosive welding.

Exceptionally high detonation velocity allowed producing continuous and wavy interface through the entire length of the weld. Melted areas consisted of various microstructural com- 

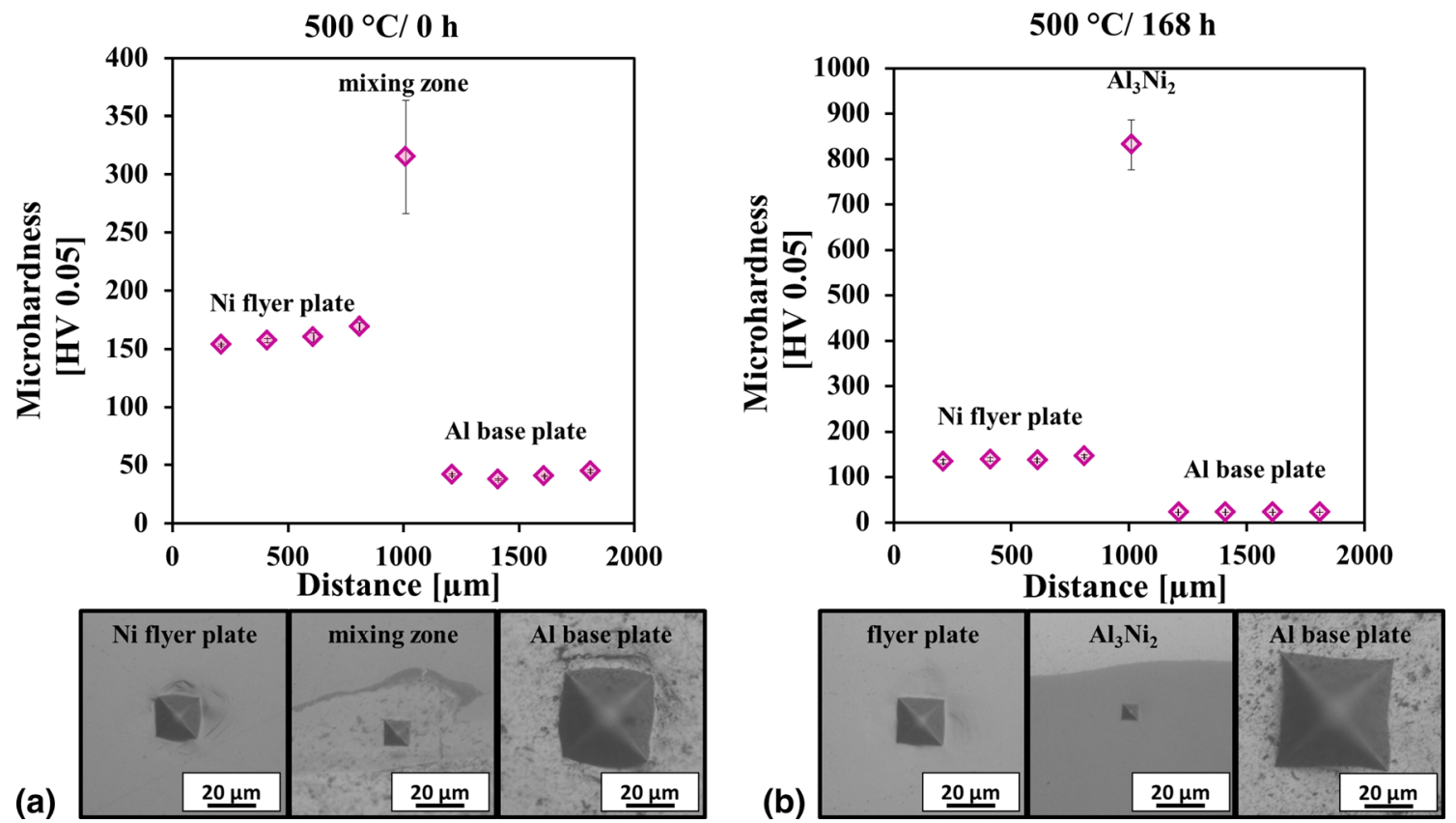

Fig. 9 Changes of the microhardness with the corresponding images of the indents for the particular zones in EXW clads before (a) and after annealing at $500{ }^{\circ} \mathrm{C}$ for $168 \mathrm{~h}(\mathrm{~b})$

ponents and were characterized by distinctly heterogeneous chemical composition being result of strong mixing of alloys during collision. Due to extreme conditions of pressure and locally higher temperature at the colliding interfaces, inside of the mixing zones stable phases $\mathrm{Al}_{3} \mathrm{Ni}, \mathrm{Al}_{3} \mathrm{Ni}_{2}, \mathrm{AlNi}$ and metastable $\mathrm{Al}_{9} \mathrm{Ni}_{2}$ phase were formed. The formation of the last mentioned one is associated with high cooling rate of the melt after the welding.

Post-processing annealing in TEM allowed to exclude the presence of $\mathrm{Al}_{9} \mathrm{Ni}_{2}$, which transformed to $\mathrm{Al}_{3} \mathrm{Ni}$ and $\mathrm{Al}_{3} \mathrm{Ni}_{2}$, similar to the situation of long-term heat treatment performed for the bulk sample, where strong mixed interface transformed into continuous layers of $\mathrm{Al}_{3} \mathrm{Ni}$ and $\mathrm{Al}_{3} \mathrm{Ni}_{2}$ phases, however, the interface zone was predominated by $\mathrm{Al}_{3} \mathrm{Ni}_{2}$ phase. Additionally, third phase of slightly different contrast at the A1050/ $\mathrm{Al}_{3} \mathrm{Ni}$ interface was distinguished, which chemical composition measurements evidenced the presence of small content of iron and nickel, and dominating amount of aluminum.

Microhardness measurements revealed significant differences in cross section of the welded clads, where the highest values were obtained in areas located within the waves. Additionally, in the case of Ni201 alloy with decreasing distance toward the bond the microhardness of alloy increased, which was associated with considerable strengthening being consequence of high plastic deformation and grains' refinement in the neighborhood of colliding surfaces. Annealing at $500{ }^{\circ} \mathrm{C}$ for $168 \mathrm{~h}$ brought very strong increase in microhardness of the interface region fulfilled mostly by $\mathrm{Al}_{3} \mathrm{Ni}_{2}$ phase, reaching twice higher value than before annealing.

\section{Acknowledgments}

The research was co-financed by the European Union from resources of the European Social Fund (Project No. WNDPOWR.03.02.00-00-I043/16).

\section{Open Access}

This article is licensed under a Creative Commons Attribution 4.0 International License, which permits use, sharing, adaptation, distribution and reproduction in any medium or format, as long as you give appropriate credit to the original author(s) and the source, provide a link to the Creative Commons licence, and indicate if changes were made. The images or other third party material in this article are included in the article's Creative Commons licence, unless indicated otherwise in a credit line to the material. If material is not included in the article's Creative Commons licence and your intended use is not permitted by statutory regulation or exceeds the permitted use, you will need to obtain permission directly from the copyright holder. To view a copy of this licence, visit http://creativecommons.org/licenses/by/4.0/.

\section{References}

1. A.A. Bykov, Bimetal Production and Application, Steel Transl., 2011, 41, p 778-786. https://doi.org/10.3103/S096709121109004X

2. H. Wang and Y. Wang, High-Velocity Impact Welding Process: A Review, Metals Basel, 2019, 9, p 144. https://doi.org/10.3390/met90 20144

3. F. Findik, Recent Developments in Explosive Welding, Mater. Des., 2011, 32, p 1081-1093. https://doi.org/10.1016/j.matdes.2010.10.017

4. M. Gerland, H.N. Presles, J.P. Guin, and D. Bertheau, Explosive Cladding of Thin Ni-Film to an Aluminium Alloy, Mater. Sci. Eng., 2000, A280, p 311-319. https://doi.org/10.1016/s0921-5093(99)0069 5-4

5. T.S. Ogneva, D.V. Lazurenko, I.A. Bataev, V.I. Mali, M.A. Esikov, and A.A. Bataev, Formation of Intermetallics at the Interface of Explosively Welded Ni-Al Multilayered Composites during Annealing, IOP Conf. Ser. Mat. Sci., 2016, 124, p 1-6. https://doi.org/10.1088/ 1757-899X/124/1/012132

6. I.A. Bataev, T.S. Ogneva, A.A. Bataev, V.I. Mali, M.A. Esikov, D.V. Lazurenko, Y. Guo, and A.M. Jorge Junior, Explosive Welded Multilayer Ni-Al Composites, Mater. Des., 2015, 88, p 1082-1087. https://doi.org/10.1016/j.matdes.2015.09.103 
7. X. Guo, Y. Ma, K. Jin, H. Wang, J. Tao, and M. Fan, Effect of StandOff Distance on the Microstructure and Mechanical Properties on Ni/ Al/Ni Laminates Prepared by Explosive Bonding, J. Mater. Eng. Perform., 2017, 26, p 4235-4244. https://doi.org/10.1007/s11665-0172890-5

8. I. Kwiecien, P. Bobrowski, M. Janusz-Skuza, A. Wierzbicka-Miernik, Z. Szulc, and J. Wojewoda-Budka, Microstructure of the Interface Zone after Explosive Welding and Further Annealing of A1050/Ni201 Clads Using Various Joining Conditions, J. Mater. Sci., 2020, 55, p 9163-9172. https://doi.org/10.1007/s10853-019-04317-7

9. R. A Patterson, Fundamentals of Explosion Welding. In: ASM Handbook, Vol. 6: Welding, Brazing, and Soldering, ASM Handbook, ASM International, Materials Park, OH 1993

10. D. Kaliński, K.M. Chmielewski, and P.K. Choręgiewicz, An influence of Mechanical Mixing and Hot-Pressing on Properties of $\mathrm{NiAl} / \mathrm{Al}_{2} \mathrm{O}_{3}$ Composite, Arch. Metall. Mater., 2012, 57, p 695-702. https://doi.org/ 10.2478/v10172-012-0075-7

11. D.M. Fronczek, R. Chulist, L. Litynska-Dobrzynska, G. AlejandroLopez, A. Wierzbicka-Miernik, N. Schell, Z. Szulc, and J. Wojewoda-Budka, Microstructural and Phase Composition Differences Across the Interfaces in Al/Ti/Al Explosively Welded Clads, Metall. Mater. Trans. A, 2017, 48, p 4154-4165. https://doi.org/10.1007/s11 661-017-4169-8

12. X.Z. Li and K.H. Kuo, Decagonal quasicrystals with Different Periodicities along the Tenfold Axis in Rapidly Solidified Al-Ni Alloys, Philos. Mag. Lett., 1988, 58, p 167-171. https://doi.org/10. 1080/09500838808214749

13. C. Pohla and P.L. Ryder, Cristalline and Quasicrystalline Phases in Rapidly Solidified Al-Ni Alloys, Acta Mater., 1997, 45, p 2155-2166

14. E. Yucelen, Characterization of low-dimensional structures by advanced transmission electron microscopy, in Chapter 4: Structure of $\mathrm{Al}_{9} \mathrm{Ni}_{2}$ Precipitates in Al-Ni Alloys. Delft University of Technology, Dutch, 2011, p 91-108

15. A.I. Ustinov and S.A. Demchenkov, Influence of Metastable $\mathrm{Al}_{9} \mathrm{Ni}_{2}$ Phase on the Sequence of Phase Transformations Initiated by Heating of Al/Ni Multilayer Foils Produced by EBPVD Method, Intermetallics, 2017, 84, p 82-91. https://doi.org/10.1016/j.intermet.2017.01.005

16. K.J. Blobaum, D. Van Heerden, A.J. Gavens, and T.P. Weihs, Al/Ni Formation Reactions: Characterization of the Metastable $\mathrm{Al}_{9} \mathrm{Ni}_{2}$ Phase and Analysis of Its Formation, Acta Mater., 2003, 51, p 3871-3884. h ttps://doi.org/10.1016/S1359-6454(03)00211-8

17. P. Nash, M.F. Singleton, J.L. Murray, In Phase Diagrams of Binary Nickel Alloys, P. Nash, ed., ASM International, Materials Park, OH, 1991, p 3-11

18. M. Bina, F. Dehgani, and M. Salim, Effect of Heat Treatment on Bonding Interface in Explosive Welded Copper/Stainless Steel, Mater. Des., 2013, 45, p 504-509. https://doi.org/10.1016/j.matdes.2012.09. 037

19. L.J. Zhang, Q. Pei, J.X. Zhang, Z.Y. Bi, and P.C. Li, Study on the Microstructure and Mechanical Properties of Explosive Welded 2205/ X65 Bimetallic Sheet, Mater. Des., 2014, 64, p 462-476. https://doi. org/10.1016/j.matdes.2014.08.013

20. H. Xia, S. Wang, and H. Ben, Microstructure and Mechanical Properties of Ti/Al Explosive Cladding, Mater. Des., 2014, 56, p 1014-1019. https://doi.org/10.1016/j.matdes.2013.12.012

Publisher's Note Springer Nature remains neutral with regard to jurisdictional claims in published maps and institutional affiliations. 